\title{
Selling the Right: Republican Rhetoric and the Shaping of Party and Nation
}

\section{Katherine Rye Jewell}
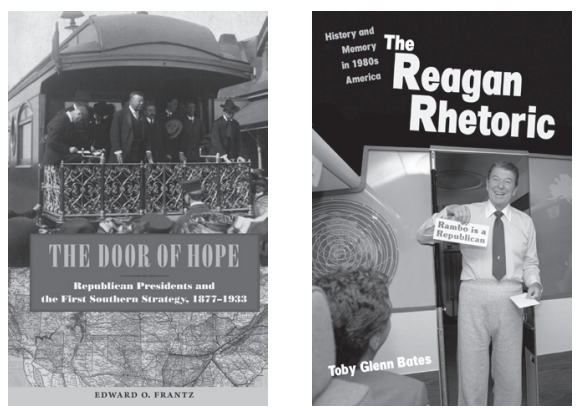

THE DOOR OF HOPE: Republican Presidents and the First Southern Strategy, 1877-1933. By Edward O. Frantz. Gainesville: University of Florida Press. 2011.

THE REAGAN RHETORIC: History and Memory in 1980s America. DeKalb: Northern Illinois University Press. 2011.

During the 1952 election, to defend his personal and political reputation, Richard Nixon took to the nation's airwaves and gave his famous "Checkers" speech. Referring to his wife's "respectable Republican coat," Nixon countered charges of improper use of campaign gifts and funds by asserting his family's modest means and history of hard work and public service. His one caveat: he would keep "Checkers," the black-and-white pup gifted to the family, because his children adored their new pet. The speech, given in the midst of the first televised presidential campaign, marked a turning point in presidential politics and media relations. Presidential rhetoric moved from out of the shadows of radio and into full view; image and appearance rose in importance alongside policy and presidential actions. As president, Ronald Reagan-, the former actor 
turned "Great Communicator" — mastered this new style of politics. The "party of Reagan" is as much a reflection of modern American political culture as it is the New Right grassroots movement of the 1960s and 1970s. Reagan's ability to fuse disparate factions of conservatives - social and religious conservatives, neoconservatives, Wall Street business interests, and white southerners-into a political juggernaut owed as much to his rhetoric as to his policies. Nixon's foray into televised politics presaged Reagan's command of the medium but could only begin to approach the former General Electric Theater star's finesse. Much had changed in political culture since Woodrow Wilson held the first press conference in 1913, let alone the age of whistle-stop tours.

Nixon in 1952 and Reagan in 1980 not only occupied different political cultures, but also very different Republican parties. The distance between the political culture of the 1950 s and that of the 1980s has received intense scholarly focus for nearly three decades. The rise of the organizational and grassroots conservative movement, the changing role of media and technology, and the demands of liberal internationalism shaped a new GOP by the time of the 1980 "Reagan Revolution." Civil rights, the culture wars, stagflation, tax revolt, and Vietnam reshaped American politics, and during the 1960s Republicans at last broke oneparty rule in Dixie. A region once lost to the party of Lincoln became crucial to Reagan's success, with Nixon having made inroads in 1968 and 1972. Eisenhower and Hoover managed to swing the outer South, but generally speaking, before the 1970s the Deep South remained out of reach of Republican candidates.

Together, Edward Frantz and Toby Bates blur the distinction between the Republican Party of post-Reconstruction and post-Reagan Revolution as well as the political culture of pre- and post-television ages. Region, the input of advisers and planners, the crafters of message, remain factors in the eras of both trains and television. Together, the books reveal that presidents' words, their meaning, and legacy bridge technological gaps, and suggest that the political culture of the late twentieth, and perhaps twenty-first, century United States is not that far removed from post-Reconstruction style politics after all. Their two books demonstrate that presidential rhetoric has been and remains a significant factor in political culture and collective memory.

The Door of Hope demonstrates the GOP's focus on the South and the transformation in its regional approach during the post-Reconstruction era. His thesis is ambitious: through the Republican presidential tours of southern states from Hayes to Hoover, "we see how the party of Lincoln became the party of Reagan" (3). Frantz advances the idea that the GOP became the "vehicle of white resentment," invoking Reagan's Neshoba speech in 1980, but he looks to the post-Reconstruction years to understand how southern presidential tours shaped the Republican Party strategy towards the region. Deemphasizing Nixon as the southern strategy's master, Frantz shows that the GOP experienced myriad internal divisions and "centrifugal forces" (2) between 1877 and 1933 but nevertheless developed a southern rhetorical and electoral strategy. Frantz's story is a tragic one. Republican leaders chose sectional harmony and economic prosperity 
over justice and full citizenship for African Americans and delayed resolution of sectional tensions, pioneering a political strategy that culminated in 1980 .

Republicans learned to be silent on southern issues to attract white voters. The tours, which Frantz calls an emerging political institution, helped the GOP shed its party of the North label and association with commitment to African American rights. By reorienting the story of reunion back into the political, a change from historians like David Blight and Nina Silber who focus more on cultural contexts, Frantz places importance on the transition from the partisan to pluralist system of governance. As party and patronage waned and the activist impulse for government grew, rhetoric became an increasingly important component of the "modern" presidency. Frantz argues that presidential personality emerges as a more important category of analysis. This study, he argues, "makes clear that presidential personality had as much to do with the function of the presidency as anything else" (7-8).

Frantz's chapters follow a similar structure: an election overview, the tour's background and planning, the tour itself, contemporary responses, and consideration of the tour's legacy. Rutherford B. Hayes's contested election in 1877 provides the natural starting point. The country faced a feeble end to Reconstruction, an economic crisis unleashing strikes and riots across the industries, and westward expansion, complete with the battles between the U.S. army and resistant native groups. Sectional reconciliation remained Hayes's central goal, and he naively continued to believe that a cross-racial party was possible. The tour occurred at the high point of Hayes's popularity, but his message of unity collapsed under divergent interests, revealing the pressure on Republicans to bridge demands from white and black southerners. Hayes's commitment to unity trended toward compromise on African American rights, particularly when he doled out patronage to southern Democrats - despite his attempts to appear high minded and fair. Press reaction both North and South proved mixed, reflecting the still shaky status of reunion. Southern editors charged that Hayes misunderstood the South and intended to subvert Democrats opportunistically, while northern editorials suggested Hayes betrayed the war's goals and might abandon Republicans. Though the tour revealed that the GOP had hope for the South, buoyed by greater returns in border states in 1880, Democratic power in Congress and committees compromised his presidency. Hayes failed to use the tour as a bully pulpit.

A southern strategy appears more clearly during Benjamin Harrison's presidential tour, particularly in the context of the Gilded Age's political climate and rising racial violence in the South. Republicans' sacrifice of African American rights for political gain emerges clearly with Harrison. While Hayes's tour showed signs of appeasement towards whites, Harrison strategically employed this approach to gain political ground for 1892. Harrison carefully planned his appearances and locations, and he invoked abstract legal rhetoric rather than strong denunciations of racial violence. Metaphor and obliqueness were hallmarks of Harrison's politics. Frantz argues, "Law became the code word for race," by 
which "Harrison sheltered himself from white southern abuse, but also limited the effect of his words on local and national audiences" (71), a fact that did not escape members of the black press. Despite conciliation to white southerners, the tour did not translate into GOP electoral success or challenge the Populists. Its legacy, however, was Republican acquiescence to Jim Crow laws, trading appeasement for political expediency, giving way to 1890s hypersectionalism and the increasing intertwining of race and politics.

McKinley's silence on racial terrorism compounded the trends of Harrison's 1891 tour. Patronage and Republican rhetoric revealed an emergent truth: reserve on racial terror and downplaying African Americans' mistreatment bought white celebration of national unity. The McKinley chapters make the case that tendency towards silence among GOP leaders "set a precedent" (107) for the party's future. The black press's fiery criticism demonstrated contemporary understanding of the importance of McKinley's silences. While the tour in 1898 occurred mostly to bolster national unity in light of the Spanish-American War, again it did little to aid GOP gains in the South. Sectional unity did not translate into a stronger Republican Party in the South, either among whites or African Americans. Despite his electoral success, Frantz argues that McKinley squandered an opportunity, and even more tragically, futilely weakened support among African Americans upon a failed strategy to woo white southerners.

Frantz accepts and expands Louis Gould's characterization of McKinley as the first modern president with his evolving the party's emerging southern strategy. In his second tour, the reelected president made direct overtures to southern whites via policy as well as rhetoric, including a weakened tariff position favorable to the agricultural South. In South Carolina, where African Americans headed the GOP, McKinley refused to acknowledge state recommendations for appointments. Even his White House management revealed a more modern bent, such as presidential secretary George Cortelyou's, who acted like a chief of staff, fielding requests and planning the trip (118). On tour, McKinley again avoided controversy by limiting appearances before blacks to educational institutions, a comparatively non-divisive issue that would not provoke demagogues, particularly because schools embraced self-help and a more conservative message. Frantz gives McKinley scant moral ground, arguing that such appearances at best "could be seen as palliatives directed towards an already hostile African American community" or at worst, "a cynical move to deceive a time-honored constituency" (128). Above all, McKinley's appeal to sectional interests appeared suspect to most African American observers during his 1901 tour; the president, if he succeeded in uniting whites nationally and bringing the Republican Party south, would produce a nation with more rigid color lines.

Frantz challenges the depiction of Roosevelt's racial thinking as "schizophrenic" and the progressive-minded president appears as a complicated, compromised change agent. Despite his use of the "bully pulpit," Roosevelt in this treatment appears as more a victim of the racial atmosphere than as attempting to broker between whites and blacks. His persona caused headaches involving 
several racial incidents Frantz discusses, such as a Booker T. Washington dinner early in the term. Roosevelt distanced his administration, unlike McKinley, from troublesome lily-white factions within the GOP in the South. He pursued an appointment strategy that selected highly "quality and visible" (159) nominees, rather than increasing black nominees outright. However, even inviting a figure such as Washington, lauded among racially conservative whites, provoked strong backlash, undermining the president. Roosevelt's presidential tour in this lengthy chapter punctuates Roosevelt's increasingly tepid response to racial injustice. In the Brownsville incident, for example, Roosevelt dismissed African American infantry soldiers allegedly involved in a deadly bar brawl near Brownsville, Texas, after he uncritically accepted white leaders' account of events. The Brownsville incident appeared alongside criticism of Roosevelt's southern tour, during which he "made no serious attempt to interact with [African Americans] in any serious or meaningful way" (183), stepping even further back than McKinley had with his black college appearances. Roosevelt continued to justify his actions, and the president's rhetoric about improving American life clashed with his "distancing" from African Americans, which befuddled and hurt members of the black press and community. Roosevelt's presidency marked a point of no return where "the 'door of hope' appeared to have been slammed shut" (193).

With the Lincoln legacy of liberation firmly in the past, the Taft and Hoover tours compounded the new lily-white vision for the party. Taft avoided even symbolic overtures to black audiences and organizations. Sectionalism and race still dominated politics, with the Republican leader appealing more overtly to white concerns. At one appearance, Taft told his audience he would not ask the South to "give up a single one of her noble traditions" (219). African American organizations largely gave up on appealing for the president's attention. Taft traveled more than previous presidents, and though Frantz asserts that the southern tour remained important, the rotund president's desire to secure the Upper South and use appearances for political gain appear more clearly, in addition to revealing more instances of coded language. For Herbert Hoover, the southern strategy became a campaign tactic. Hoover's appearance at Elizabethton, Tennessee, an example of New South industrial growth, featured no mention of African Americans, even symbolic. While previous Republican presidents had "balanced" the expectations of black and white southerners, Hoover tipped the balance solidly toward whites. Looking beyond his Democratic opponent's liabilities in the South stemming from religion and culture, Hoover made important overtures to white southerners to counteract concerns that the GOP would interfere with the affairs of Dixie. Indeed, Frantz telescopes his argument, arguing, "the southern strategies of Dwight D. Eisenhower, Richard Nixon, and Ronald Reagan all owed limited methodological and ideological debts to Herbert Hoover" (244).

Though the GOP had only mixed success fulfilling the process set in motion by Hayes in the post-Reconstruction era, and Frantz argues that television and radio made tours obsolete, Hoover's southern strategy, shaped by his GOP forbears, blurs the lines between party and politicking in the 1877-1933 era. Republicans 
did not consign the South to a hopeless one-party region; Frantz demonstrates that Dixie remained a constant feature in the party's planning through the fifty years following Reconstruction. The "silver lining" Frantz finds in his story, is that the southern strategy's solidification by Hoover's presidency paved a clearer path for African Americans to abandon the party of Lincoln in their search for recognition and enforcement of their democratic rights.

Frantz may indeed be guilty of telescoping to Reagan with his argument's implications, to co-opt Matthew Lassiter's phrase. Certainly, 1928 is an imperfect ending in many ways. Through the 1940s the Republican Party remained the stronghold of support for policies to benefit African Americans-anti-poll tax legislation, the Fair Employment Practices Commission, even though policies alienated white southern support. The immediate result was that African Americans more readily abandoned party loyalty, but white southerners remained solidly Democratic, and the GOP only began to build party infrastructure in the region in the 1950s and 1960s, long after the southern strategy origins Frantz outlines. After all, southern Democrats switching to the GOP is a 1960s phenomenon and is a change that must be understood in the context of suburbanization and economic development, as scholars like Matthew Lassiter and Joseph Crespino have shown. Hanging the change on the rhetoric of Republican presidents in the South is a hefty task, though Frantz makes important contributions to the role of rhetoric and race in Republican politics in the South.

Frantz highlights sectionalism as the central issue in the GOP's problematic post-Reconstruction relationship with the South and demonstrates that reconciliation continued to influence Republican politics in the twentieth century. Such rhetorical continuity restores regional politics and the varieties in presidents' regional strategies to political history. Republican presidents' divergent approaches resulted in a lessening commitment to black civil rights below the Mason-Dixon Line. Frantz reconstructs the complicated political and partisan context behind this development rather than relying merely on racial politics. He does blame Republicans for adopting two approaches to race, paternalistic or pseudo-scientific, and for accepting Booker T. Washington's gradualism. The narrowing of focus on white southerners through the course of his story and the growing sense of futility among the African American press demonstrates this transformation. Yet, African Americans themselves were divided on tactics. For GOP leaders, political pragmatism was at work in addition to deeply held racial convictions. Frantz's argument accepts that multiple forces existed within the GOP, but by telescoping forward, the outcome shades what could be an even more dynamic exploration of the various forces - from both whites and blacks - that shaped the rhetoric of Republican presidents towards the South. Frantz overturns the general thesis that the GOP merely ignored black voters after Reconstruction until 1944 as the New Deal lured them to the Democrats. His study begs for more analysis of the GOP in the 1940s and 1950s, particularly the party's 1944 platform and support for fair employment, given his suggestion that the twentieth century was a "struggle" to "fulfill the vision of southern success" (244). 
Frantz also reminds historians of the myriad ways presidents make policy. For the post-Reconstruction era, appointments and patronage continued to play an important role. For the presidents Frantz studies, the connection between rhetoric and policy is strong, and should remind historians interested in policy of the importance of what presidents say, in addition to what they do. Indeed, Toby Bates's study of presidential rhetoric during the Reagan years compounds this lesson, demonstrating how rhetoric connects to policy, with one reinforcing the other, but also how rhetoric can shape and reshape memory and history.

Bates examines the history, rhetoric, and memory associated with Ronald Reagan's public persona. Bates's analysis focuses on Reagan's rhetoric in three areas. First, he focuses on the Great Communicator's relationship with region and the development, over time, of the mythology surrounding Reagan's early 1980 campaign speech in Philadelphia, Mississippi, where he referenced his respect for "states' rights," long accepted as code for anti-civil rights positions. Second, the book's most substantial portion recounts Reagan's "consistent messaging" on Vietnam, where the government failed to support victory, war protesters served as the enemy's dupes, with veterans as the primary victims. Bates argues that Reagan's use of the bully pulpit influenced popular opinions regarding the war, which filtered into and shaped narratives in popular culture. Lastly, Bates examines Reagan's initial failure at consistency regarding Iran-Contra and his support for anti-communist rebels. This uncharacteristic lack of consistency, Bates argues, paradoxically facilitated Reagan's political survival.

Three sections facilitate Bates's larger argument that Reagan effectively "generate[d] change in the present" (6) and shaped national memory, and that he "blurred the boundary between history and memory" (7). Regional differences in the Neshoba speech coverage led to incorrect assertions by both campaign workers and critics. But, ultimately, Reagan emerged the victor. Reagan's key strength was his ability to shape the moment, as Bates argues, "The majority of the nation remembered the Mississippi speech exactly how Reagan wanted them to - in other words, not at all" (160). Reagan's victory appears more pronounced regarding Vietnam, where Reagan's confidence in the nation's ability to move beyond the conflict indeed shaped a reworking of collective memory regarding the war. Building on his interpretation that consistency of message facilitated the president's survival and success in politics, Bates's argument regarding IranContra highlights Reagan's likability. Ultimately, Nancy Reagan helped preserve her husband's memory as he faded into Alzheimer's. The "key elements" of Reagan's rhetoric became collective memory. His retreat from public life meant that Americans "had nowhere to look but to better days/nostalgia" (155).

Bates bridges political history and cultural history with his examination of responses to Reagan's appearance at the Neshoba County Fair in Philadelphia, Mississippi. Based largely on conversations among Reagan's staffers and regional and national news coverage, Bates reconstructs not just the speech, but how Reagan's rhetoric at that time and place signaled the transformation of both Mississippi and the candidate. A close event reconstruction reveals that several 


\section{Katherine Rye Jewell}

mythologies emerged, including reported (and inaccurate) audience cheers at Reagan's "states' rights" pledge and the fallacy that the event marked the launch of his 1980 presidential campaign. The media furor that ensued drew from the 1964 Freedom Summer murders that took place not far from the speech location. Nationally, the speech revived the region's "bloodstained memory," as Bates put it, whereas locally, the speech appealed. Despite contradictory reactions and sensitive issues, Bates argues that the speech “demonstrated not only Reagan's ability to survive a potentially fatal rhetorical gaffe but also his linguistic skill to satisfy both the national and the local memories swirling around the rural Mississippi location" (22). Just as post-Reconstruction presidents navigated the tempestuous waters of reunification and side-stepped racial tensions, Reagan similarly was able to defuse the event, but for different reasons.

Bates argues that Reagan's political survival, which surprised aides who believed the speech was a disaster, owed to the candidate's consistency, his ability to reach out to black voters, and the dominance of economic issues in the 1980 campaign. Reagan had used the states' rights language repeatedly in several speeches and in private correspondence. At the event itself, Bates notes that Reagan's diction and his past use of the phrase helped prove he had not intended it as coded language for white Mississippians. Staffers feared the national backlash, however, which did take place. Reagan's subsequent appearances before the National Urban League, appearances in places like the South Bronx, and visits with Jesse Jackson generated laudatory media coverage for Reagan's willingness to converse over difficult issues with black America. Moreover, the media sided with Reagan's version of events in the 1980 campaign season, painting Carter's attempts to revive the issue as mean politics.

In the long term, the Neshoba incident continued to stir debate about the place of race in conservative politics, particularly once the Reagan administration amassed a policy record "indifferent" (37), in Bates's words, to affirmative action and civil rights issues. Looking at his presidency in retrospect caused observers to attribute more meaning to the Neshoba appearance than contemporary accounts. After 1989, Bates point out that even historians have accepted the storied version of the appearance, and he amasses an impressive list of offenders in the text. Nevertheless, Bates's argument that Reagan's rhetoric effectively placated Mississippi and national audiences, audiences with vastly disparate memories of the civil rights movement and the 1964 murders near Neshoba, "demonstrates the importance of memory as well as Reagan's ability to make his audience serve his needs" (43).

Reagan's ability to shape audiences' interpretations appears stronger regarding Vietnam memory. The Great Communicator's consistent messaging, Bates argues, helped reshape national attitudes towards the conflict. The consistent themes he struck included: Vietnam was part of a global struggle against communist expansion and was thus a "noble cause"; the Vietnam veteran was an innocent victim, they fought gallantly yet were betrayed by Congress; and war protesters served as "the dupes of America's enemies" (45-46). Reagan made 
effective use of the bully pulpit to advance his narrative, such as his support for the Vietnam Veterans' Memorial and the belated Congressional Medal of Honor presentation to Sergeant Roy Benavidez in 1981. Bates explains, "The unexplained wait in the awarding of the medal provided Reagan a sinister example for a president advocating a thesis of American government apathy toward the Vietnam soldier" (57).

Reagan's efforts shaped popular perception of the war, a change visible by 1984. Veterans' groups repeatedly sought Reagan's appearance and lauded his actions in supporting the memorial. Letters to the president demonstrated that his words had effect and support Bates's contention that Reagan's rhetoric was central to shifting views towards Vietnam. Reagan's rhetoric appears strongest in Bates's treatment of the Vietnam narrative. He argues, "The power of the presidency combined with Reagan's rhetoric and soon produced a certain acceptance of particular elements of his Vietnam language" (63). The causal argument that presidential rhetoric contains the power to shape popular opinion and memory of a collective past appears most strongly in this section.

Support for this position continues in the next two chapters, which focus entirely on popular culture. With Reagan's rhetoric and consistent messaging established, Bates moves to trace the narrative in 1980s popular culture. In these chapters Reagan is a diminished figure, with his words and actions seldom appearing. Rambo and Platoon represented a "crescendo" of the new depiction of Vietnam veterans. The former is the perfect vessel for the Reagan rhetoric. As Bates argues, the Stallone flick "displays the exact influence" of Reagan's consistent messaging on Vietnam. First Blood (Part I) reveals the new rhetoric, identical to the presidents' messaging, whereas Part II exhibits that message at its peak. While Part I features Rambo, the betrayed soldier who was not "allowed" to win by his government and had to watch his brothers in arms get literally blown away, Part II, Bates argues, turns the government into Rambo's ally and then traitor. Part II reenacts the government's betrayal of Vietnam veterans. Similarly, Platoon depicts the brutality of war and echoes the theme of the deceived recruit ensnared in a war he did not choose. Although Oliver Stone's film has a more complicated relationship to Reagan's rhetoric, Bates uses the example to show how even popular culture not consciously supporting the new narrative ends up recreating Reagan's themes. The film's apolitical nature “echoed Reagan's avoidance of any debate regarding the war" (83). Popular culture reflected revised collective memory regarding the war, despite the political resistance of many critics. Similarly, television and comic books brought this new narrative forward. Stories focused on the individual experiences of soldiers while avoiding the political conversations that dominated 1960s and 1970s culture, whether laudatory or critical. Like The A-Team, Tour of Duty, and China Beach, found on $\mathrm{NBC}, \mathrm{CBS}$, and $\mathrm{ABC}$, respectively, television focused on the shared experiences of war while also highlighting the experience of individuals in a broader "chaos not of their making" (96). Marvel Comics followed a similar individual plot line that focused on the individual soldier while avoiding politics, and then 
when the new narrative seemed entrenched, comics and their audiences moved forward. Popular culture also reflected changes in Reagan's rhetoric. The ATeam mirrored the Rambo franchise's Part III, a box office bust. Bates argues that NBC's cancellation of The A-Team coincided with Part III's flop because American tastes changed, matching Reagan's softer rhetoric towards communism in light of Soviet reforms.

Consistency and inconsistency as the core of Reagan's rhetoric appears strongest in Bates's discussion of Iran-Contra. Reagan's greatest quality emerges as consistent rhetoric, both in dealing with scandal and in shaping scandal's aftermath, despite early problems. His consistent support of anti-communist Nicaraguan rebels became a liability, unlike his consistent messaging on Vietnam memory. Compounded by tough talk against Iran and terrorism, after the arms trade for hostages with proceeds shunted to the rebels made headlines, Reagan seemed to have betrayed his own clear-cut rhetoric. In particular, Reagan's refusal to condemn the transaction compounded his appearance of inconsistency. The president's handling of the scandal, Bates argues, in particular his self-imposed silence on the matter, exacerbated public distrust but ultimately secured the president's political survival. His ability to maintain personal distance while admitting administrative responsibility saved Reagan's reputation and legacy. Bates cites the August 12, 1987 address on the crisis in which Reagan dropped the clause "I'm angry," but left "I've been mad as a hornet" (148). Dropping the present tense gave rise to the idea that he was moving forward, and the president's rhetoric indicated that he confidently accepted his own explanation of the scandal's cause. Circumstance limits Bates's argument about the power of Reagan's messaging; media reports confirmed the president's detailing of events because no other evidence surfaced. However, the president successfully relegated the story to the back burner, and his popularity regained ground lost by the fall of 1987. Whereas the Brownsville incident plagued Teddy Roosevelt, who continued to rationalize and justify his actions, Reagan's rhetoric allowed the scandal to recede.

Religion is surprisingly absent from Bates's treatment of Reagan's rhetoric, explained by Bates's focus on Reagan and the American people. Yet readers might appreciate Bates's fresh analysis applied to how this messaging played at home, not just in foreign policy, particularly in popular culture, the author's forte, and regarding the emerging culture wars. Treatment of Reagan's rhetoric within the domestic arena is needed; scholarly analysis of Reagan's rhetoric largely focuses on foreign policy and strong statements about the evils of communism. In analyzing the relationship between the president and the public, specifically regarding memory, Bates explains a defining aspect of Reagan's appeal. With this broader view, the two Vietnam popular culture chapters appear superfluous because they reinforce a single argument. The real estate might have been better used for an examination of Reagan's cross-class appeal, which is touched on only tangentially throughout the book. 
Bates remains refreshingly neutral in his stance towards the Reagan "mythology" mentioned by several recent studies on the fortieth president. He does not grapple with the political question of a "Reagan Revolution" or if Reagan fundamentally transformed the nation into a center-right electorate. Bates nevertheless helps explain the popularity and magnitude of Reagan's image, a position acceptable to those who revere or despise him. Neither is this a presidential study in the vein of John William Ward's Andrew Jackson: Symbol for an Age, nor does Bates approach Gil Troy's Morning in America argument regarding the convergence of Reagan and the 1980s. However, Bates does accept the idea of the 1980s as the "Reagan years," where the White House defined the national character equal to Kennedy's Camelot. Bates's contribution to the idea of the Age of Reagan is to demonstrate how Reagan "challenged the present thinking of millions by offering new perspectives and interpretations" (17).

Bates and Frantz occupy similar territory, turning soft areas of presidential activity into dynamic spaces of policy creation and politicking. Political developments have strong ties with culture and vice versa, a fact well known to scholars of the new political history. Whereas presidents and their rhetoric can define an era, so too can their policies and rhetoric, even when limited, shape political legacies. Rhetoric and policy need not be tied to the mediums through which they are communicated, as these studies demonstrate. Taken together, Door of Hope and The Reagan Rhetoric demonstrate a long trend in GOP politics towards the South and raise presidential rhetoric to the center of the discussion, complicating and historicizing the idea of coded language. Regarding presidents and their audiences, particularly the press, local and national contexts and conflicts shade the relationship, whether messages come through speeches at colleges or via comic books. Furthermore, political strategizing and presidential image transcends technological changes, and broad relationships between parties and regions develop through historical processes and across administrations. The presidential bully pulpit influences more than public opinion; it shapes memory and national unity across eras. Public appearances, however orchestrated or conducted for political or partisan gain are important to political culture and policy developments, as well as to the construction of historical meaning and memory. 
